\title{
Effect of Nanoencapsulated Pre-emergence Sulfentrazone Herbicide on Soil Microbiome and Nodulation of Irrigated Blackgram (Vigna mungo L.)
}

\author{
Vikram Kannamreddy ${ }^{1}$, C. R. Chinnamuthu ${ }^{1}$, \\ S. Marimuthu ${ }^{2}$ and C. Bharathi ${ }^{1}$ \\ ${ }^{1}$ Department of Agronomy, ${ }^{2}$ Department of Nano Science and Technology, Tamil Nadu \\ Agricultural University, Coimbatore - 641003, India \\ *Corresponding author
}

\section{A B S T R A C T}

\section{Keywords \\ Leachability, Nodulation, Solvent evaporation}

Article Info

Accepted:

14 June 2020

Available Online:

10 July 2020
Field experiments were conducted in the wetland farms of Department of Agronomy, Tamil Nadu Agricultural University, Coimbatore during Rabi and Summer 2019-2020. Both the experimental trials consists of nine treatments of randomized block design which were replicated thrice. The treatments comprise of sulfentrazone with and without encapsulation @ $0.30 \mathrm{~kg} \mathrm{ha}^{-1}$ applied at 1 DBS and 2 DAS followed by general recommended herbicides and weed management methods for blackgram. Sulfentrazone herbicide was encapsulated by using solvent evaporation method for season long weed management and to reduce the leachability. These treatments were tested to know their effect on soil bacterial, fungal and actinomycetes population and also the nodulation ability of blackgram crop. All the herbicide applied treatments were showed reduction in bacterial, fungal and actinomycetes population at 25 DAS compared to initial population, but slight increase in the population of $\mathrm{T}_{7}$ (Two hand weedings at 15 and $30 \mathrm{DAS}$ ), $\mathrm{T}_{8}$ (Weed free check)and $\mathrm{T}_{9}$ (Absolute control)treatments in both the trials. At 50 DAS there was great increase in microbial population compared to 25 DAS in all herbicide applied treatments. There was no significant difference among all the treatments at 50 DAS in microbial population. Higher nodule count and nodule dryweight were noticed at 30 DAS in $\mathrm{T}_{9}$ (Absolute control), $\mathrm{T}_{8}$ (Weed free check) and $\mathrm{T}_{7}$ (Two hand weedings at 15 and 30 DAS) which is followed by $\mathrm{T}_{1}$ (Encapsulated sulfentrazone @ $0.30 \mathrm{~kg}$ a.i. ha ${ }^{-1}$ applied at 1 DBSand $\mathrm{T}_{6}$ (Pendimethalin @ $1 \mathrm{~kg}$ a.i. ha ${ }^{-1}$ applied at 2 DAS $f b$ hand weeding at 20 DAS). But at 60 DAS there was no significant difference among the treatments except with unweeded control.

\section{Introduction}

Soil is the restless harbour for plant growth and is the mother land for most of the microbes. Use of pesticides and fertilizers in crop protection and production affects soil in many ways. Their concentration, threshold level, half-life, movement and also type of crop that harbours the particular soil influence soil biology and ecology. Blackgram is a nutritious edible seed of leguminous crop, have become an essential part of the human diet. It is an important pulse crop cultivated in tropical and subtropical regions of the world. 
These leguminous plants are symbiotically connected with rhizobia and their interaction plays a vital role in crop growth (Vijay et al., 2018). Symbiotic nitrogen fixing ability of this crop helps in enrichment the soil, with this reason blackgram became an important crop for crop rotation. N-fixing bacteria and fungi are accountable up to $80 \%$ of nitrogen and up to $75 \%$ of phosphorus, that is assimilated by plants annually (Nongmaithem and Pal, 2013). Microorganisms are influenced by several factors including the application of herbicides (Pampulha et al., 2007). Among the different soil microbes, more sensitive microbes to herbicides are bacteria (Ghinea et al., 1998). Sulfentrazone herbicide belongs to the family of phenyl triazolinone, has mean partition coefficient $\mathrm{K}_{\mathrm{oc}}=43$ and sorption coefficient $\mathrm{K}_{\mathrm{d}}<1$ and also has high horizontal and vertical leaching potential (Martinez et al., 2008). It has high Groundwater Ubiquity Score (GUS) of 6.75 which is far more than broad spectrum herbicides like pendimethalin and glyphosate which are having GUS of 0.66 and 0.42 respectively (Gustafson, 1989). This is the prime reason for encapsulation of sulfentrazone using solvent evaporation method. This study is mainly aimed to know the effect of sulfentrazone with and without encapsulation and other different treatments on soil microbial population changes with time and also to know nodulation ability of blackgram.

\section{Materials and Methods}

Field experiments were conducted in the wetland farms of Department of Agronomy, TNAU, Coimbatore during Rabi and Summer 2019-2020. Both the experimental trials consists of nine treatments of randomized block design which were replicated thrice. The treatments are $\mathrm{T}_{1}$-Encapsulated $\left(\mathrm{e}^{+}\right)$ Sulfentrazone @ $0.3 \mathrm{~kg}$ a.i. ha ${ }^{-1}$ at $1 \mathrm{DBS}, \mathrm{T}_{2^{-}}$ Non-encapsulated(e') Sulfentrazone @ $0.3 \mathrm{~kg}$ a.i. $\mathrm{ha}^{-1} \mathrm{e}^{-}$at $1 \mathrm{DBS}, \mathrm{T}_{3}$-Sulfentrazone @ 0.3 $\mathrm{kg}$ a.i. $\mathrm{ha}^{-1} \mathrm{e}^{+}$at 2 DAS, T 4 -Sulfentrazone @ $0.3 \mathrm{~kg}$ a.i. $\mathrm{ha}^{-1} \mathrm{e}^{-}$at 2 DAS, T5-Pendimethalin @ $1.0 \mathrm{~kg}$ a.i. ha ${ }^{-1}$ at 2 DAS fb Quizalofopethyl@ $50 \mathrm{~g}$ a.i.ha ${ }^{-1}$ and Imazethapyr @ $50 \mathrm{~g}$ a.i. ha ${ }^{-1}$ at 20 DAS, T6-Pendimethalin@1.0 $\mathrm{kg}$ a.i. ha ${ }^{-1}$ at $2 \mathrm{DAS}$ fb $1 \mathrm{HW}$ at $20 \mathrm{DAS}^{-\mathrm{T}_{7-}}$ $\mathrm{HW}$ twice at 15 and $30 \mathrm{DAS}, \mathrm{T}_{8}$-Weed free check and $\mathrm{T}_{9}$-Absolute control.

The soil type of the field trials is clay loam in texture, slightly basic $\mathrm{pH}(8.4)$, low EC (0.43 $\left.\mathrm{dSm}^{-1}\right)$, medium in organic carbon $(0.70$ per cent), low in available $\mathrm{N}\left(263.5 \mathrm{~kg} \mathrm{ha}^{-1}\right)$, medium in available $\mathrm{P}_{2} \mathrm{O}_{5}\left(15.2 \mathrm{~kg} \mathrm{ha}^{-1}\right)$ and high in available $\mathrm{K}\left(891.7 \mathrm{~kg} \mathrm{ha}^{-1}\right)$. Proper need based crop management practices and plant protection measures were followed in all the treatments as per the crop production guide, TNAU, 2019. Microbial population dynamics in various treatments was studied from the experimental soil before sowing, at 25 and 50 DAS by serial dilution plate count technique. Weighed and transferred 1 gram of soil in to $10 \mathrm{ml}$ sterile distilled water and shaked rigorously. This gives $10^{-1}$ dilution, from this $1 \mathrm{ml}$ of suspension was transferred to $9 \mathrm{ml}$ of sterile distilled water using a sterile pippete to get $10^{-2}$ dilution. Consequent $10^{-3}$, $10^{-4} 10^{-5}$ and $10^{-6}$ dilutions were made similarly. The appropriate media viz., nutrient agar, rose bengalagar and kenknightagar for bacteria, fungi and actinomycetes respectively were melted, cooled and poured in to sterile petri plates by pour plate method carrying respective dilution. Petri plates were incubated at $30^{\circ} \mathrm{C}, 2$ days, 4 days and 7 days for bacteria, fungi and actinomycetes respectively. After incubation time, emerged colonies were counted and expressed as CFU per gram of soil. For nodule count and dryweight five plants were selected and pulled out after giving irrigation then counted No. of nodules per plant. After that nodules were collected, shade dried and taken dry weight per plant in $\mathrm{mg}$ plant $^{-1}$ at 30 and 60 DAS. 


\section{Results and Discussion}

\section{Effect on soil microbiome}

All the herbicide applied treatments were showed reduction in bacterial, fungal and actinomycetes population at 25 DAS compared to initial population, but slight increase in the population of $\mathrm{T}_{7}, \mathrm{~T}_{8}$ and $\mathrm{T}_{9}$ treatments in both the trials. At 50 DAS there was great increase in microbial population compared to 25 DAS in all herbicide applied treatments. There was no significant difference among all the treatments at 50 DAS in microbial population. This might be due to carbon released from degraded herbicide leads to an increase of the soil microflora population (Bera and Ghosh, 2013). In sulfentrazone applied plots initially at 25 DAS there was less bacterial, fungal and actinomycetes population compared to control. But at 50 DAS there was gradual increase in population of microbes (Table 1 and Table 2). This was supported by Sulfentrazone applied to sugarcane crop at lower doses of 720 and $840 \mathrm{~g}$ a.i. ha ${ }^{-1}$ did not affect the microflora but in case of higher doses of 1320 and $2400 \mathrm{~g}$ a.i. $\mathrm{ha}^{-1}$ initial reduction of microflora was observed and recovered 30 days after application (Kalaiyarasi, 2012).

\section{Effect on nodulation of blackgram}

Higher nodule count and nodule dryweight were noticed at 30 DAS in $\mathrm{T}_{9}$ (Absolute control), $\mathrm{T}_{8}$ (Weed free check) and $\mathrm{T}_{7}$ (Two hand weedings at 15 and 30 DAS) which is followed by $T_{1}$ (Encapsulated sulfentrazone @ $0.30 \mathrm{~kg}$ a.i. $\mathrm{ha}^{-1}$ applied at $1 \mathrm{DBSand} \mathrm{T}_{6}$ (Pendimethalin@1 @g a.i.ha ${ }^{-1}$ applied at 2 DAS $f b$ hand weeding at 20 DAS). But at 60 DAS there was no significant difference among the treatments except with unweeded control. At 60 DAS higher nodule count and nodule dry weight were noticed in $\mathrm{T}_{8}$ and $\mathrm{T}_{7}$ followed by $\mathrm{T}_{6}, \mathrm{~T}_{5}$ (Pendimethalin @ $1.0 \mathrm{~kg}$ a.i. ha ${ }^{-1}$ at 2 DAS $f b$ Quizalofop-ethyl @ $50 \mathrm{~g}$ a.i. ha ${ }^{-1}$ and Imazethapyr @ 50 g a.i. ha ${ }^{-1}$ at 20 DAS) and $\mathrm{T}_{1}$ (Encapsulated sulfentrazone @ $0.3 \mathrm{~kg}$ a.i. ha ${ }^{-1}$ at $1 \mathrm{DBS}$ ).According to Raman and Krishnamoorthy (2005) nodulation in black gram was not affected significantly due to the application of chemical herbicides. With this experiment it was found that sulfentrazone with and without encapsulation @ $0.30 \mathrm{~kg}$ a.i. $\mathrm{ha}^{-1}$ applied at 1 DBS and 2 DAS did not differ significantly with others except absolute controlin both nodule number and dryweight (Table 3). Pendimethalin, imazethapyr and quizalofop-ethyl also did not affect the nodule number and dryweight. Similar observations were recorded by Mishra and Chandra Bhanu (2006).

Hence concluded, in both the field experiments conducted during Rabi and Summer 2019-2020, it was observed that all the herbicide applied treatments were showed reduction in microbial count at 25 DAS compared to initial population. There was no significant difference among all the treatments at 50 DAS in microbial population. Higher nodule count and nodule dryweight were noticed at 30 DAS in Absolute control, Weed free check and Two hand weedings at 15 and 30 DAS which are followed by Encapsulated sulfentrazone @ $0.30 \mathrm{~kg}$ a.i. ha ${ }^{1}$ applied at 1 DBS and Pendimethalin@ @ $1 \mathrm{~kg}$ a.i. ha ${ }^{-1}$ applied at 2 DAS $f b$ hand weeding at 20 DAS.But at 60 DAS there was no significant difference among the treatments except with unweeded control. In this experiment it is concluded that in sulfentrazone@0.30 kg a.i. ha ${ }^{-1}$ with and without encapsulation and also in other herbicidal treatments even though there was slight decrease in microbial population, nodule count and nodule dryweight at initial stages of blackgram, later due to herbicidal degradation by microbes there was gradual increase in soil microbiome and nodulation ability. 
Table.1 Effect of weed management treatments on microbial population (CFU) of soil in trial I

\begin{tabular}{|c|c|c|c|c|c|c|c|}
\hline \multirow{2}{*}{$\begin{array}{l}\text { T. } \\
\text { No. }\end{array}$} & \multirow[b]{2}{*}{ Treatments } & \multicolumn{3}{|c|}{25 DAS } & \multicolumn{3}{|c|}{50 DAS } \\
\hline & & $\begin{array}{l}\text { Bacteria } \\
\left(\mathrm{x} 10^{6}\right. \\
\mathrm{CFU})\end{array}$ & $\begin{array}{l}\text { Fungi } \\
\left(\mathrm{x} 10^{4}\right. \\
\text { CFU) }\end{array}$ & $\begin{array}{l}\text { Actinomycetes } \\
\left.\text { (x } 10^{3} \mathrm{CFU}\right)\end{array}$ & $\begin{array}{c}\text { Bacteria } \\
\left(\mathrm{x} 10^{6} \mathrm{CFU}\right)\end{array}$ & $\begin{array}{c}\text { Fungi } \\
\left.\text { (x } 10^{4} \mathrm{CFU}\right)\end{array}$ & $\begin{array}{c}\text { Actinomycetes } \\
\left.\text { (x } 10^{3} \mathrm{CFU}\right)\end{array}$ \\
\hline $\mathbf{T}_{1}$ & Sulfentrazone@0.3 kg a.i. ha ${ }^{-1} \mathrm{e}^{+}$at 1 DBS & 30.96 & 8.33 & 18.18 & 45.99 & 14.72 & 24.98 \\
\hline $\mathbf{T}_{2}$ & Sulfentrazone@0.3 kg a.i. ha ${ }^{-1} \mathrm{e}^{-}$at 1 DBS & 30.31 & 8.17 & 17.86 & 45.25 & 14.70 & 24.46 \\
\hline $\mathbf{T}_{3}$ & Sulfentrazone@0.3 kg a.i. ha ${ }^{-1} \mathrm{e}^{+}$at 2 DAS & 30.95 & 7.58 & 17.58 & 45.35 & 14.59 & 24.27 \\
\hline $\mathbf{T}_{4}$ & Sulfentrazone@0.3 kg a.i. ha ${ }^{-1} \mathrm{e}^{-}$at 2 DAS & 30.92 & 7.53 & 17.51 & 45.24 & 14.51 & 24.29 \\
\hline $\mathbf{T}_{5}$ & $\begin{array}{l}\text { Pendimethalin@1.0 kg a.i. ha }{ }^{-1} \text { at } 2 \text { DAS } \\
\text { fbQuizalofop-ethyl @ } 50 \mathrm{~g} \text { a.i. ha }{ }^{-1} \text { and } \\
\text { Imazethapyr @ } 50 \mathrm{~g} \text { a.i. ha }{ }^{-1} \text { at } 20 \text { DAS }\end{array}$ & 29.75 & 7.79 & 17.05 & 47.51 & 14.86 & 25.47 \\
\hline $\mathbf{T}_{6}$ & $\begin{array}{l}\text { Pendimethalin @ } 1.0 \mathrm{~kg} \text { a.i. } \mathrm{ha}^{-1} \text { at } 2 \mathrm{DAS} \\
f b 1 \mathrm{HW} \text { at } 20 \mathrm{DAS}\end{array}$ & 33.85 & 9.25 & 18.37 & 48.41 & 15.39 & 26.47 \\
\hline $\mathbf{T}_{7}$ & HW twice at 15 and 30 DAS & 43.55 & 12.25 & 22.67 & 48.50 & 15.79 & 27.20 \\
\hline $\mathbf{T}_{8}$ & Weed free check & 44.51 & 12.08 & 22.74 & 48.45 & 16.39 & 26.90 \\
\hline \multirow[t]{3}{*}{$\mathbf{T}_{9}$} & Absolute control & 46.90 & 11.67 & 23.48 & 48.34 & 15.49 & 27.30 \\
\hline & SEd & 2.31 & 0.84 & 0.83 & 2.74 & 0.79 & 1.51 \\
\hline & $\mathrm{CD}(\mathrm{P}=0.05)$ & 4.89 & 1.79 & 1.76 & NS & NS & NS \\
\hline
\end{tabular}


Table.2 Effect of weed management treatments on microbial population (CFU) of soil in trial II

\begin{tabular}{|c|c|c|c|c|c|c|c|}
\hline \multirow{2}{*}{$\begin{array}{l}\text { T. } \\
\text { No. }\end{array}$} & \multirow[b]{2}{*}{ Treatments } & \multicolumn{3}{|c|}{25 DAS } & \multicolumn{3}{|c|}{50 DAS } \\
\hline & & $\begin{array}{l}\text { Bacteria } \\
\left(\mathrm{x} 10^{6}\right. \\
\mathrm{CFU})\end{array}$ & $\begin{array}{l}\text { Fungi } \\
\left(\mathrm{x} 10^{4}\right. \\
\mathrm{CFU})\end{array}$ & $\begin{array}{l}\text { Actinomycetes } \\
\left(\mathrm{x} 10^{3} \mathrm{CFU}\right)\end{array}$ & $\begin{array}{l}\text { Bacteria } \\
\left(\mathrm{x} 10^{6}\right. \\
\mathrm{CFU})\end{array}$ & $\begin{array}{l}\text { Fungi } \\
\left(\mathrm{x} 10^{4}\right. \\
\text { CFU) }\end{array}$ & $\begin{array}{l}\text { Actinomycetes } \\
\left(\mathrm{x} 10^{3} \mathrm{CFU}\right)\end{array}$ \\
\hline $\mathbf{T}_{1}$ & Sulfentrazone@0.3 kg a.i. ha ${ }^{-1} \mathrm{e}^{+}$at 1 DBS & 27.57 & 7.33 & 15.40 & 42.17 & 14.42 & 21.42 \\
\hline $\mathbf{T}_{2}$ & Sulfentrazone@0.3 kg a.i. ha ${ }^{-1} \mathrm{e}^{-}$at 1 DBS & 26.89 & 7.33 & 15.04 & 41.48 & 14.10 & 21.02 \\
\hline $\mathbf{T}_{3}$ & Sulfentrazone @0.3 kg a.i. ha ${ }^{-1} \mathrm{e}^{+}$at 2 DAS & 27.62 & 6.33 & 14.58 & 41.58 & 14.36 & 21.05 \\
\hline $\mathbf{T}_{4}$ & Sulfentrazone@0.3 kg a.i. ha ${ }^{-1} \mathrm{e}^{-}$at 2 DAS & 27.54 & 6.67 & 14.06 & 41.19 & 14.08 & 20.55 \\
\hline $\mathbf{T}_{5}$ & 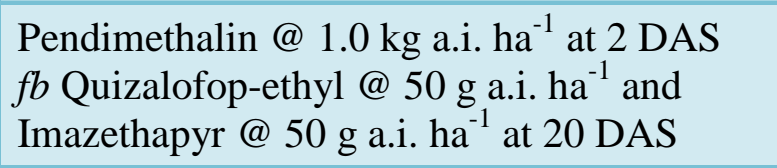 & 26.56 & 6.00 & 14.15 & 43.50 & 14.28 & 21.84 \\
\hline $\mathbf{T}_{6}$ & $\begin{array}{l}\text { Pendimethalin@1.0 kg a.i. ha }{ }^{-1} \text { at } 2 \text { DAS } \\
f b 1 \mathrm{HW} \text { at } 20 \text { DAS }\end{array}$ & 31.35 & 7.33 & 15.60 & 43.77 & 14.92 & 22.66 \\
\hline $\mathbf{T}_{7}$ & HW twice at 15 and 30 DAS & 38.79 & 10.33 & 20.70 & 44.08 & 15.33 & 23.28 \\
\hline $\mathbf{T}_{\mathbf{8}}$ & Weed free check & 39.63 & 11.33 & 20.47 & 44.03 & 16.17 & 22.92 \\
\hline \multirow[t]{3}{*}{$\mathbf{T}_{9}$} & Absolute control & 41.84 & 9.33 & 21.29 & 44.35 & 15.00 & 23.43 \\
\hline & SEd & 1.94 & 0.60 & 0.86 & 2.35 & 0.72 & 1.23 \\
\hline & $\mathrm{CD}(\mathrm{P}=0.05)$ & 4.11 & 1.27 & 1.83 & NS & NS & NS \\
\hline
\end{tabular}


Table.3 Effect of weed management treatments on nodule count (No.plant ${ }^{-1}$ ) and nodule dryweight $\left(\mathrm{mg} \mathrm{plant}^{-1}\right)$ of blackgram in trial I and II

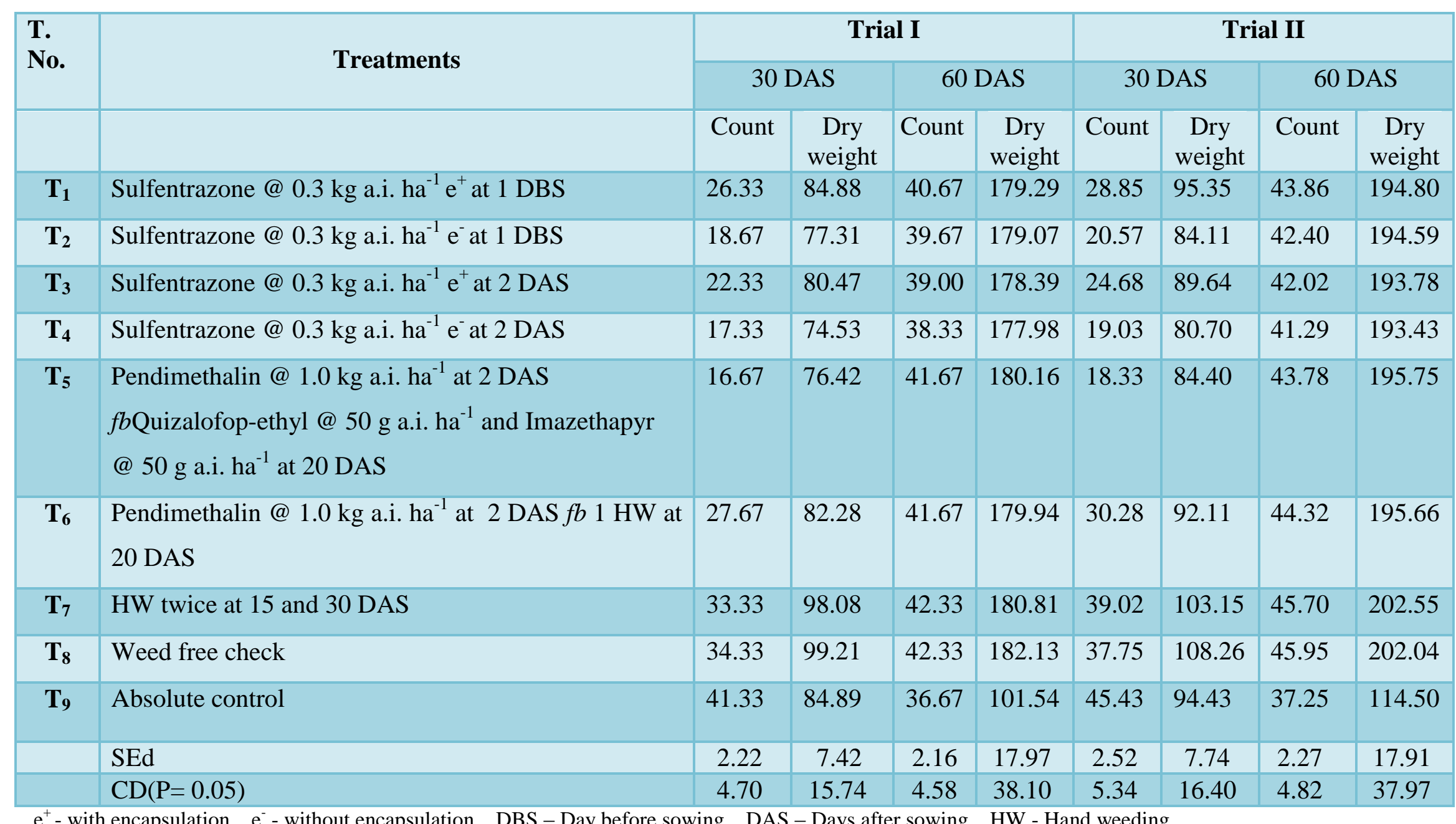




\section{References}

Bera, S., and Ghosh, R. K. (2013). Soil microflora and weed management as influenced by atrazine 50\% WP in sugarcane. Universal Journal of Agricultural Research, 1(2), 41-47.

Ghinea, L., Lancu, M., Turcu, M. and Stefanic, G. (1998). The impact of sulfonyl-urea and non-selective herbicides on biological activity of sandy soils. Rom. Agric. Res. 9(1): 5557.

Gustafson, D. I. (1989). Groundwater ubiquity score: a simple method for assessing pesticide leachability. Environmental Toxicology and Chemistry: An International Journal, 8(4), 339-357.

Kalaiyarasi, D. (2012). Evaluation of sulfentrazone for weed control in sugarcane and its residual effect on succeeding crops (Doctoral dissertation, Ph. D. Thesis, Tamil Nadu Agricultural University, Coimbatore).

Martinez, C. O., Silva, C. M. M., Fay, E. F., Maia, A. D. H. N., Abakerli, R. B., and Durrant, L. R. (2008). Degradation of the herbicide sulfentrazone in a Brazilian Typic Hapludox soil. Soil Biology and Biochemistry, 40(4), 879-
886.

Mishra, J.S. and Chandrabhanu. (2006). Effect of herbicides on weeds, nodulation and growth of Rhizobium in summer blackgram (Vigno mungo L.). Indian Journal of Weed Science, 38: 150-153.

Nongmaithem, D., and Pal, D. (2013). Effect Of Different Weed Management Practices On Soil Bacterial Population Under Different Crops. The Bioscan, 8(4), 1241-1245.

Pampulha, M. E., Ferreira, M. A. S. S., and Oliveira, A. (2007). Effects of a phosphinothricin based herbicide on selected groups of soil microorganisms. Journal of basic microbiology, 47(4), 325-331.

Raman, R. and R. Krishnamoorthy. (2005). Nodulation and yield of mungbean [Vigna radiata (L.)] influenced by integrated weed management practices. Legume Research, 28(2): 128-130.

Vijay, R., Ravichandran, V., and Boominathan, P. (2018). Non-Rhizobial Nodule Associated Bacteria (NAB) From Blackgram (Vigna mungo L.) and their possible role in plant growth promotion. Madras Agricultural Journal, 106(march (1-3)), 1.

\section{How to cite this article:}

Vikram Kannamreddy, C. R. Chinnamuthu, S. Marimuthu and Bharathi, C. 2020. Effect of Nanoencapsulated Pre-emergence Sulfentrazone Herbicide on Soil Microbiome and Nodulation of Irrigated Blackgram (Vigna mungo L.). Int.J.Curr.Microbiol.App.Sci. 9(07): 1348-1354. doi: https://doi.org/10.20546/ijcmas.2020.907.156 